\title{
Improvement of Strength Characteristics of Lateritic Sub-Grade Soil with Shredded Polyethylene Waste
}

\author{
*11OJURI OO \\ ${ }^{1}$ Department of Civil and Environmental Engineering, Federal University of Technology, Akure, Nigeria \\ Email: ooojuri@futa.edu.ng
}

\begin{abstract}
This paper presents the results of investigation of the behavior of pavement subgrade soil stabilized with shredded polyethylene waste. Shredded high density polyethylene High Density Polyethylene Waste of maximum size $20 \times 25 \mathrm{~mm}$ was used for the improvement of lateritic soil at various percentages which are; $1 \%, 2 \%, 3 \%, 4 \%$, and $5 \%$ respectively. Series of laboratory tests such as, Compaction and California Bearing Ratio (CBR) were conducted to determine the influence of polyethylene waste on the lateritic soil. The results reveal that addition of polyethylene waste to the soil increased the optimum moisture content (OMC) but, reduced the maximum dry density (MDD) from $2338.60 \mathrm{~kg} / \mathrm{m}^{3}$ to $1941.64 \mathrm{~kg} / \mathrm{m}^{3}$. A decrease in the dry density of soil sample shows that low comparative energy would be required for the soil to attain its maximum dry density; as a result the cost of compaction is significantly reduced. Improvement in CBR values was also observed for laterite-polyethylene mixture; resulting in maximum CBR value of $13.18 \%$ under soaked condition. This value falls within the range of $10 \%$ to $25 \%$ CBR value specified for sub grade soils by the AASHTO standard and the Nigerian Highway Design Manual, Federal Ministry of Works and Housing. An increase in the California Bearing Ratio value can significantly reduce the total thickness of the pavement; hence, the total cost involved in the project. The strength of Lateritic clay subgrade soils can be improved with the addition of five percent (5\%) Shredded high density polyethylene (HDPE) Waste of maximum size $20 \times 25 \mathrm{~mm}$. (C) JASEM
\end{abstract}

http://dx.doi.org/10.4314/jasem.v20i3.21

Keywords: Lateritic soil, High density polyethylene (HDPE) waste, Pavement thickness, Sub-grade soil

\section{INTRODUCTION}

The need for adequate provision of transportation facilities is enormously increasing with increase in population and also the need for maintenance of the existing ones. Highway engineers are faced with the problems of providing very suitable materials for the highway construction. Predicated on this fact, continuous researches are being carried out by individuals, firms and institutions on ways to improve the engineering properties of soils. The most available soils do not have adequate engineering properties to really bear the expected wheel loads. Consequently, improvisations have to be made to make these soils better. These lead to the concept called soil stabilization which is the alteration of soils to enhance their engineering properties in order to allow in-situ construction. It is any treatment applied to soil to improve its strength and reduce its vulnerability to water ingression. If the treated soil is able to withstand the stresses imposed on it by traffic under all weather conditions without excessive deformation, then it is generally regarded as stable.
Several highways pavement in Nigeria are failing due to the use of soil with inadequate engineering strength. Hence the need for improvement of the engineering properties of soil has been a paramount concern to Transportation and Geotechnical Engineers (Amadi, 2014). The ability to blend the naturally abundant lateritic soil with some appropriate additives to give it better engineering properties in both strength and waterproofing characteristics has been of great importance to the Transportation engineers (Gidigasu, 1976). In bid to improve the engineering properties of soil to make it suitable for road construction, several researches on soil stabilization have been carried out. This research work, therefore, was undertaken to investigate soil improvement using Shredded high density polyethylene (HDPE) Waste.

The non degradable thermoplastic polyethylene used for commodity goods storage and packaging purposes accounts for over 60 million tons of annual wastes generation worldwide (Justo and Vaeeraragaven, 2002). It was also reported that $30 \%$ of the domestic waste in a typical Nigerian city 
comprises of the polyethylene and plastic products in very large quantities; whose disposal has continued to constitute the great environmental pollution challenge and concern in big and small cities (Jimoh and Kolo, 2011).The enormity of the problem of the pure water sachets is better imagined during or immediately after rains in urban areas, where the highway drainage channels conveniently serve as the dumping sites for the polyethylene bags. However, consideration of processing this expedient material for a better alternative use by recycling it to other beneficial products, can contribute more positively to the material cost reduction; health, safety and environment (HSE) compliance in construction of pavement works. Road pavement asphaltic concrete have been improved with tires, plastics, pipes and cement admixtures in physical shreds as reinforced fiber (Singh and Singh, 1983); oil shale modified asphalt, (Katamine, 2000); plastic waste rubbles as aggregates in concrete pavements, (Zoorob and Superman, 2000). Shredded plastics have been applied as successful bitumen modifier in asphalt mixes, (Singh and Singh 1991). The economic and environmental advantage of alternative use of these products has been demonstrated by Jimoh and Kolo (2010) with the reprocessed polyethylene pure water sachet modification of the optimum bitumen binder in asphalt mix production, but with partial replacement only. The objective of this research work is the application of shredded high density polyethylene wastes in the improvement of the compaction and strength characteristics of a lateritic soil.

\section{MATERIAL AND METHODS}

Study Area: Akure is a growing urban area within latitudes $7 \circ \quad 10 \square \mathrm{N}$ and $7 \circ \quad 20 \square \mathrm{N}$ and between longitudes $5^{\circ} 07 \square \mathrm{E}$ and $5^{\circ} 17 \square \mathrm{E}$ in Ondo State, Nigeria. The mean annual temperature ranges between $24^{\circ} \mathrm{C}-27^{\circ} \mathrm{C}$, while the annual rainfall, varies between $1500 \mathrm{~mm}$ and $3500 \mathrm{~mm}$.

Materials Preparation and Characterization: The materials used for this research are basically lateritic soil and Shredded HDPE. The lateritic soil sample was collected inside Federal University of Technology, Akure, Ondo State, Nigeria, behind the new Academic building. It belongs to the group of ferruginous tropical soils derived from igneous and metamorphic soil disintegration rocks. The soil sample is reddish brown in color and it was collected as disturbed sample from a pit at depths of $1 \mathrm{~m}$ from the ground surface. The materials used in the study were high density polyethylene (HDPE) waste and lateritic soil (Plate 1 and Plate 2). Despite their names (HDPE or LDPE) the difference in density is very small. To ascertain the type of HDPE, melting temperature was used, which agrees with the works of (Wienaah, 2007). Melting temperatures for HDPE and LDPE ranges from $120^{\circ} \mathrm{C}$ to $126^{\circ} \mathrm{C}$ and $110{ }^{\circ} \mathrm{C}$ to $115^{\circ} \mathrm{C}$ respectively (Wienaah, 2007 , BPF, 2015). HDPE waste was obtained from the Business Development Company (BDC) sachet water factory of the Federal University of Technology, Akure (FUTA). The physical properties of the HDPE are summarized in Table 1. The polyethylene waste was washed thoroughly and sundried to complete dryness; after which it was shredded into different sizes. The material was shredded into distinct rectangular dimensions using scissors at the Geotechnical Laboratory, FUTA.

Table 1 Physical properties of High Density Polyethylene

\begin{tabular}{|c|c|c|c|}
\hline HDPE Properties & Conventional/Standard (BPF, 2015) & Used & Standards \\
\hline Tensile Strength $\left(\mathrm{N} / \mathrm{mm}^{2}\right)$ & $0.20-0.40$ & 0.36 & ASTM D882-12 (2012) \\
\hline Specific Gravity & $0.94-0.96$ & 0.94 & ASTM D792 (2008) \\
\hline Thermal Coefficient of Expansion & $100-220 \times 10^{-6}$ & $210 \times 10^{-6}$ & ASTM D696-08e1 (2008) \\
\hline Melting Point $\left({ }^{\circ} \mathrm{C}\right)$ & $120-126$ & 120 & ASTM D440-15 (2015) \\
\hline Density $\left(\mathrm{g} / \mathrm{cm}^{3}\right)$ & $0.941-0.965$ & 0.95 & ASTM D792 (2008) \\
\hline Thickness (mm) & $0.1-0.2$ & 0.125 & ASTM D5199 (2012) \\
\hline
\end{tabular}

Basic index tests were performed for the purpose of identifying and classifying the soil used, these include; moisture content, grain size distribution, specific gravity, and Atterberg's limit (Das, 2002). Table 2 shows the basic index properties values of lateritic soil used in this study. 
Table 2 Basic index properties of lateritic soil

\begin{tabular}{ll}
\hline \multicolumn{1}{c}{ Index properties } & values \\
\hline Moisture content & $7.89 \%$ \\
Specific gravity & 2.65 \\
Percentage finer than sieve No 200 & $55.34 \%$ \\
Liquid limit & $44.00 \%$ \\
Plastic limit & $41.00 \%$ \\
Plasticity index & $3.00 \%$ \\
\hline
\end{tabular}

The natural moisture content of the soil was $7.89 \%$, while specific gravity was 2.65 . The result of grain size analysis shows that the lateritic soil contains silt

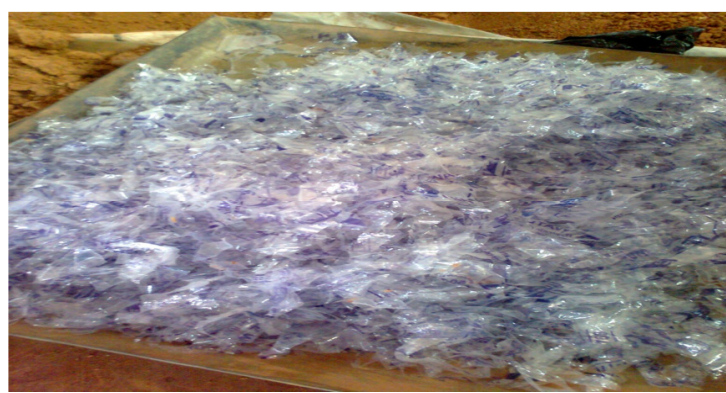

Plate 1: Shredded Polyethylene waste

Procedure: The following experiments were performed on the lateritic soil: particle size distribution in accordance with B.S 1377:1990 Part 2:9; Atterberg's limit test in accordance with B.S. 1377:1990, part 2:4,2:5 and 2:6; specific gravity test in accordance with B.S. 1377:1990, part 2:8; moisture content test in accordance with B.S. 1377:1990, part 2:3; compaction test in accordance with B.S. 1377:1990, part 4:4 and California bearing Ratio (CBR): B.S. 1377:1990, part 4:7.

\section{RESULTS AND DISCUSSION}

The Compaction curves for natural soil and soil improved with HDPE is presented in Figure 1. The compaction process for the lateritic soil-HDPE waste mixture is as shown in Plate 3. The shape of the compaction curves obtained show an increase in dry and clay content of $55.34 \%$, which was subjected to hydrometer analysis for complete particle size analysis. The soil was poorly graded when plotted on sieve analysis graph. According to AASHTO classification system, the lateritic soil used belongs to group A-6.The results of Atterberg's limit tests consisting; Liquid Limit (LL), Plastic Limit (PL) and Plasticity Index (PI) were $44.0 \%, 41.0 \%$ and 3.0 respectively; while the shrinkage limit was found to be

$11.02 \%$.

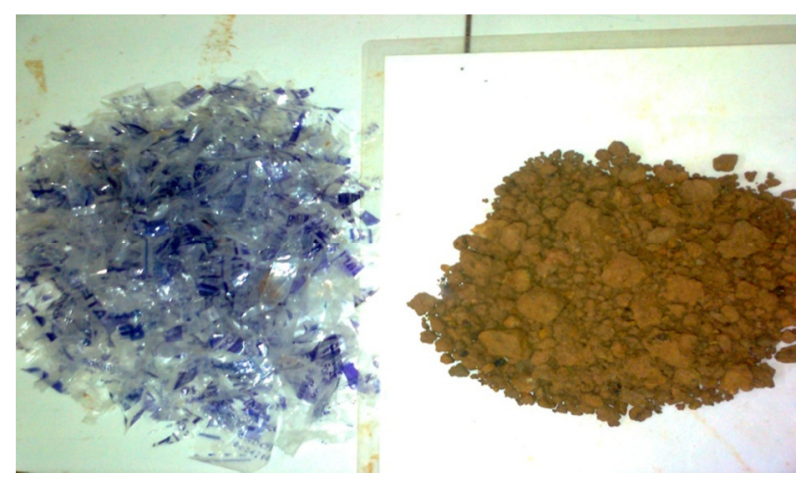

Plate 2: L-R, Shredded Polyethylene waste, and Lateritic soil

density with moisture content to a maximum value and then a decrease with further increases in moisture content. The increase in dry density was attributed to the lubrication of the particles from water addition; resulting in a denser packing arrangement. The effectiveness of the moisture addition diminished at wet of optimum conditions as indicated by reduction in dry density due to the replacement of solids with water. Generally, the relative locations of the compaction curves for unimproved and improved soil revealed that lower compactive effort would be required by stabilized soil to reach its peak dry density. However, the maximum dry density of stabilized soil which is lower than that of unstabilized soil was considered not to have an adverse effect on the sub-grade since it's of adequate CBR. 


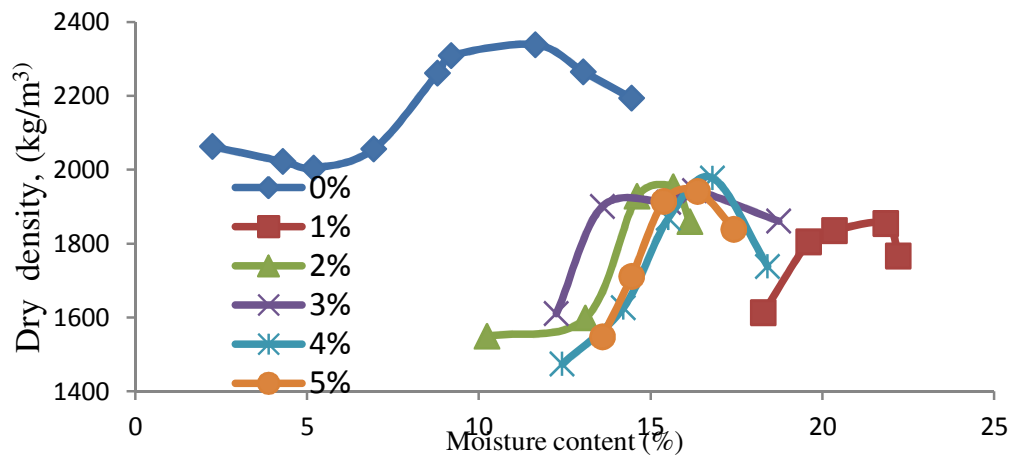

Fig. 1: Compaction curves for natural soil and soil improved with High Density Polyethylene

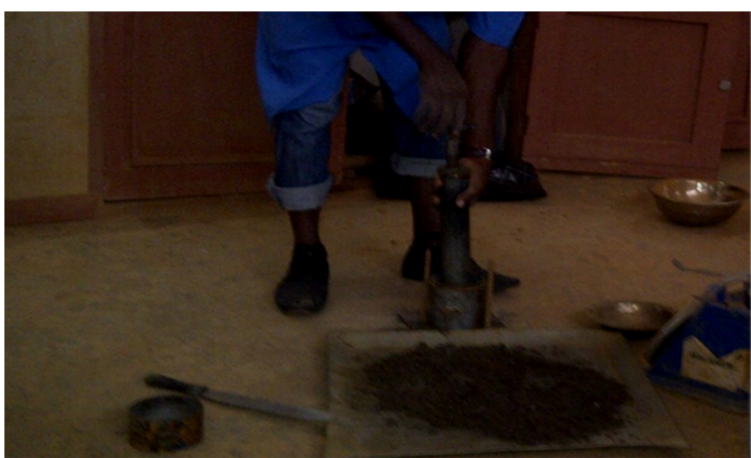

Plate 3: Compaction process for the lateritic soilHigh Density Polyethylene waste mixture

The optimum moisture content (OMC) for the unstabilized soil sample is $11.65 \%$ with the maximum dry density (MDD) of $2338.6 \mathrm{Kg} / \mathrm{m}^{3}$. The addition of HDPE of $1 \%, 2 \%, 3 \%, 4 \%$ and5\% by weight of the soil sample, increased OMC significantly and decreased MDD of the stabilized soil samples. The OMC increased from $11.65 \%$ to the highest which is $21.85 \%$; while the MDD decreased from $2338.6 \mathrm{~kg} / \mathrm{m}^{3}$ to $1854.32 \mathrm{~kg} / \mathrm{m}^{3}$. The result shows that there was a reduction in the maximum dry density and an increase in the optimum moisture content. According to Muntohar and Hantoro (2000), a decrease in the dry density of lateritic soil-HDPE waste mixture sample shows that low comparative energy would be required for the soil to attain its maximum dry density; as a result the cost of compaction would be significantly reduced. The variation in Optimum Moisture Content (OMC) and Maximum Dry Density (MDD) of various lateritic soil - polyethylene waste mixtures are shown in Figure 2 and Figure 3 respectively.

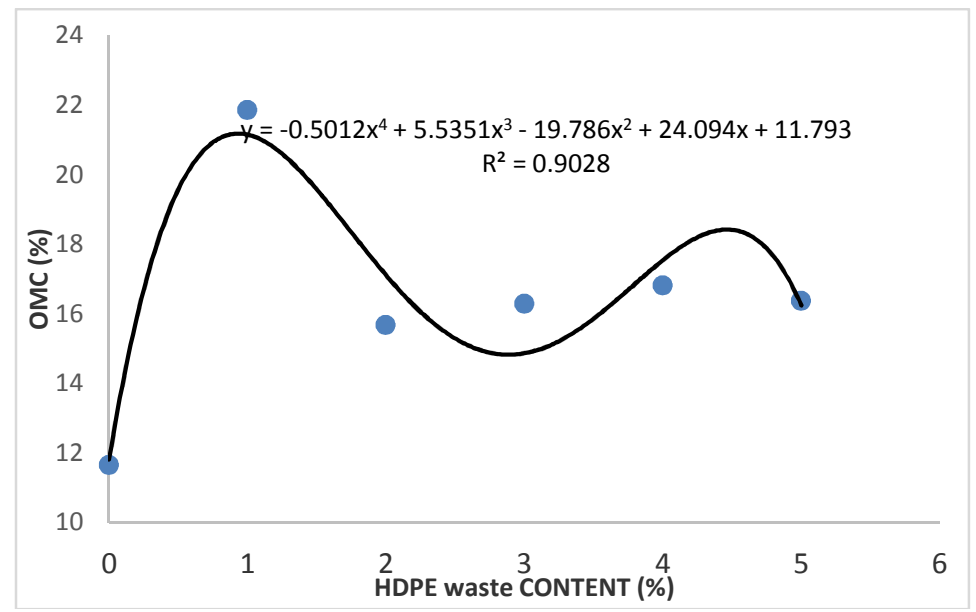

Fig. 2: Variation of Optimum Water Content (OMC) with Shredded high density polyethylene (HDPE) waste Content 


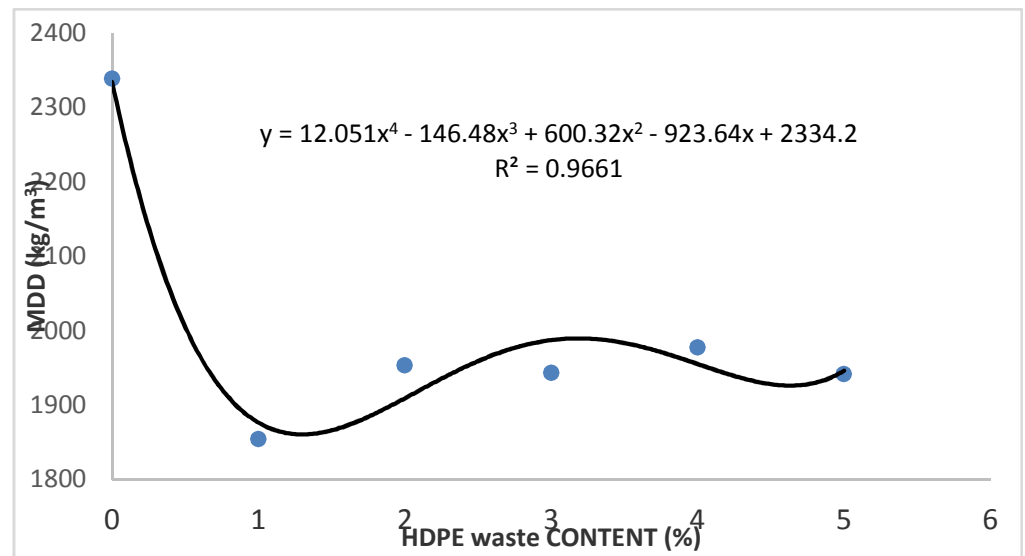

Fig. 3: Variation of Maximum Dry Density (MDD) with Shredded high density polyethylene (HDPE) waste Content

The load penetration curves obtained from the CBR tests for un-stabilized and stabilized soil sample; with HDPE contents at various percentages $(1 \%, 2 \%, 3 \%$, $4 \%$ and $5 \%$ ) is presented in Figure 4. The CBR values of the un-stabilized soil sample corresponding to $2.5 \mathrm{~mm}$ or $5.0 \mathrm{~mm}$ penetration were found to be 4.13 and 2.64 for un-soaked and soaked conditions respectively. These increased to 6.82 and 9.06 for unsoaked and soaked conditions respectively, when soil was stabilized with $1 \%$ of HDPE. The CBR value also increased for soil sample improved with $2 \%$ of HDPE. Further increase in HDPE percentage resulted in increased CBR values of the stabilized soil as determined from the load-penetration curve; the values are summarized in Table 2 . The increase in the California Bearing Ratio (CBR) with increase in shredded polyethylene waste content is an indication of the strength and stiffness of the lateritic soil-HDPE waste mixture. This is in agreement with the results obtained by Kalumba 2010 and Mahali and Sinha 2015 for similar soil improvement experiments with plastic wastes. HDPE material mixed with soil showed a continuous improvement in CBR values with its addition up to 5\%. Maximum CBR value was $13.18 \%$ under soaked condition; this CBR value for sub grade soils lies within the range (10\% to $25 \%$ ) specified as per AASHTO standards. The Highway Design Manual, Federal Ministry of Works and Housing specification of soil characteristics for flexible pavement design specifies CBR value $10 \%$ minimum (soaked) for subgrade soil. Therefore, the best strength would be gotten by addition of $5 \%$ HDPE. An increase in the CBR value would significantly reduce the total thickness of the pavement; hence, the total cost of the project.

Table 2: Summary of California Bearing Ratio (CBR) test results

\begin{tabular}{clcc}
\hline S/N & \multicolumn{1}{c}{ Description } & $\begin{array}{c}\text { Unsoaked } \\
\text { CBR (\%) }\end{array}$ & Soaked CBR (\%) \\
\hline $\mathbf{1}$ & Un-stabilized soil & 4.13 & 2.64 \\
$\mathbf{2}$ & Soil stabilized with 1\% HDPE & 6.82 & 9.06 \\
$\mathbf{3}$ & Soil stabilized with 2\% HDPE & 9.69 & 9.74 \\
$\mathbf{4}$ & Soil stabilized with 3\% HDPE & 9.86 & 11.12 \\
$\mathbf{5}$ & Soil stabilized with 4\% HDPE & 11.23 & 11.81 \\
$\mathbf{6}$ & Soil stabilized with 5\% HDPE & 14.90 & 13.18 \\
\hline
\end{tabular}




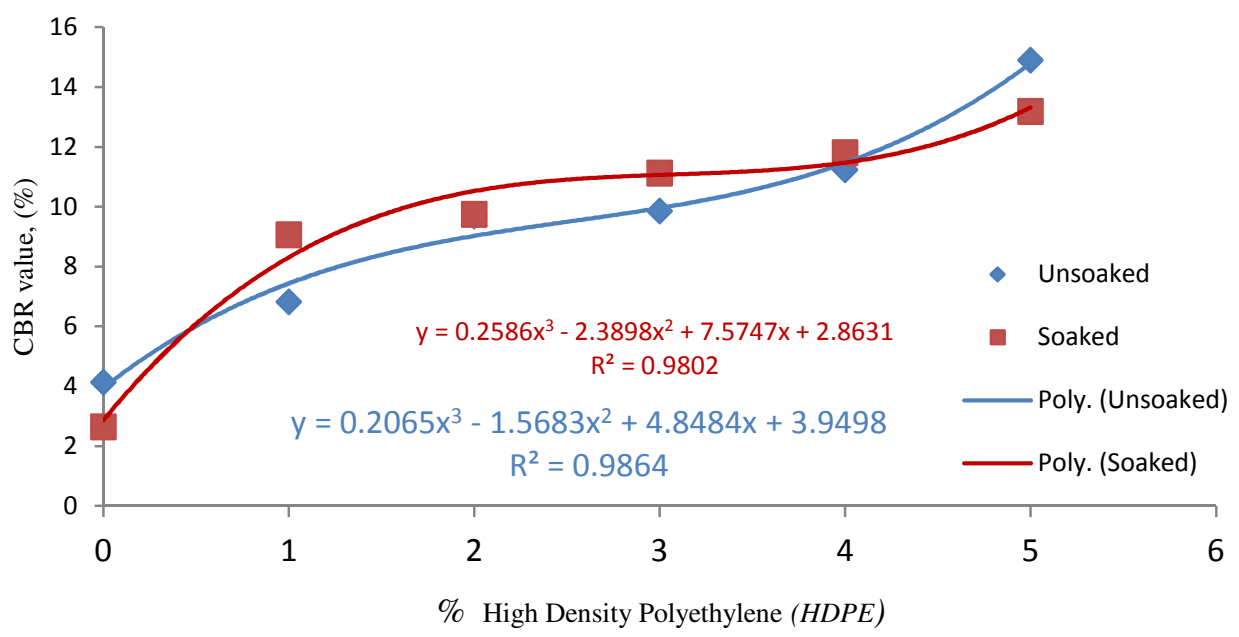

Fig. 4: Variation of California Bearing Ratio (CBR) with percentages shredded polyethylene waste

Statistical regression analysis was used to establish a mathematical relationship between Optimum Water Content (OMC) and Shredded high density polyethylene (HDPE) waste Content (Figure 4). The polynomial equation (Equation 1) gave the best trend line with a high coefficient of determination of $\mathrm{R}^{2}=$ 0.9028

$$
\begin{array}{r}
O M C=-0.5012 P^{4}+5.5351 P^{3}-19.786 P^{2}+24.094 P+ \\
11.793 \quad\left(\mathrm{R}^{2}=0.9028\right)(1)
\end{array}
$$

Where; OMC - Optimum Water Content (\%), P - HDPE waste content $(\%)$

The relationship between Maximum Dry Density (MDD) and Shredded high density polyethylene (HDPE) waste Content (Figure 5) gave the best trend line with a high coefficient of determination of $\mathrm{R}^{2}$ $=0.8762$ and a corresponding polynomial equation (Equation 2).

$$
M D D=12.051 P^{4}-146.48 P^{3}+600.32 P^{2}-923.64 P-
$$
$2334.2 \quad\left(\mathrm{R}^{2}=0.9661\right)(2)$

Where; MDD - Maximum Dry Density $\left(\mathrm{kg} / \mathrm{m}^{3}\right), \quad$ P - HDPE waste content (\%)

The quantity " $\mathrm{R}$ " " called coefficient of determination is an index of correlation between the two variables and varies between zero and one. It is always nonnegative and it is the square of the coefficient of correlation " $\mathrm{R}$ " which lies between -1 and +1 .

The relationship between Soaked and Unsoaked California Bearing Ratio (CBR) and Shredded high density polyethylene (HDPE) waste Content (Figure 6) gave the best trend line with a higher coefficient of determination of $\mathrm{R}^{2}=0.8762$ and a corresponding polynomial equation (Equation 3) for Soaked CBR and also a polynomial best trend line with a high coefficient of determination of $\mathrm{R}^{2}=0.8762$ expressed in Equation 4 for Unsoaked CBR.

Soaked $C B R=0.2065 P^{3}-1.5683 P^{2}+4.8484 P+3.9498$ $\left(\mathrm{R}^{2}=0.9864\right)(3)$
Where; CBR - California Bearing Ratio (\%), P - HDPE waste content $(\%)$

$\begin{array}{rr}\text { Unsoaked CBR }=0.2586 P^{3}-2.3898 P^{2}+7.5747 P+2.8631 \\ & \left(\mathrm{R}^{2}=0.9802\right)(4) \\ \text { Where; CBR - California Bearing Ratio (\%), } \quad \mathrm{P}-\text { HDPE waste }\end{array}$ content $(\%)$

Soaked and Unsoaked CBR values for lateritic soilHDPE waste mixtures can be predicted for specific HDPE waste content using Equation (3) and Equation (4) respectively for lateritic subgrade soils.

Conclusions: This study combined the bilateral advantage of solid waste re-use much advocated by waste management authority with improvement of sub-grade soil strength characteristics at lower cost; which leads to reduction in thickness, hence, total cost of highway pavement construction. Based on the summary of the experimental results, it can be concluded that the polyethylene (High Density Polyethylene) waste performed well as an effective stabilizer for improving the strength characteristics of lateritic soils.

Acknowledgement: The involvement of Sikiru I. $\mathrm{O}$. in data collection is acknowledged. The equipment used for this research was made available by the Department of Civil and Environmental Engineering, Federal University of Technology, Akure, Ondo State, Nigeria. The cooperation of the Head of geotechnical unit and assistance rendered by laboratory technologists is much appreciated. 


\section{REFERENCES}

Amadi, AA (2014). Enhancing durability of quarry fines modified black cotton soil subgrade with cement kiln dust stabilization. Transp. Geotech 1: 55-61

BS 1377 (1990): Method of Test for soil for civil engineering purpose, British Standard Institute, London.

British Plastics Federation (BPF) (2015). "Polyethylene (High Density) HDPE" http://www.bpf.co.uk/Plastipedia/Polymers/HDP E.aspx. Accessed on January 18, 2015

Das, B. M., (2002), Principles of Geotechnical Engineering, Fifth Edition, Brooks Cole/Thompson Learning, Pacific Grove, CA.

Gidigasu, M.D. (1976)."Lateritic Soil Engineering" Elsevier Scientific Publishing Company Amsterdam http://en.wikipedia.org/wiki/polyethylene, polyethylene, Accessed date August 8, 2006.

Jimoh YA; Kolo, SS (2010), "Partial substitution of asphalt binder with reprocessed polyethylene water sachets", NSE Technical Transactions, Journal of the Nigerian Society of Engineers, 45: $1-14$.

Jimoh YA; Kolo SS (2011) Dissolved Pure Water Sachet as a Modifier of Optimum Binder Content in Asphalt Mixes. Epistemics in Science, Engineering and Technology, 1 (4):176-184

Justo CEG, and Veeraragavan A, "Utilization of waste plastic bags in bituminous mix for improved performance of roads" Bangalore University, Bangalore India, undergraduate thesis, 2002 unpublished.

Kalumba, D. (2010) "Using shredded plastic shopping bags wastes in soil improvement" International Conference on Sustainable Built Environment (ICSBE-2010), Kandy, Sri Lanka, December 13-14, 2010, pp.257-261.

Kalumba D; Petersen MA (2010), "Using shredded plastic shopping bags in soil improvement for civil engineering projects", Proc. of 20th Waste Conference, 4-8 October, 2010 Gauteng, South Africa.
Kaniraj, SR; Havanagi, VG (2001) "Behavior of cement-stabilized fiber-reinforced fly ash-soil mixtures", J. geotech. geoenviron. eng., 127: 574-584.

Katamine NM, "Physical and mechanical properties of bitumen mixtures containing oil shale", Transp. Eng. J. ASCE, ASCE, Vol. 126, 2000, pp. $178-184$.

Kolo SS, "Effects of bitumen modification with polyethylene (PWS) in asphalt mixes for road works and pollution control", University of Ilorin, July 2008, M. Eng. Civil Thesis, Unpublished.

Kolo, SS; Jimoh, YA. (2010). Effect of dissolved waste pure water sachets on the strength properties of asphalt pavement mixes. Global Journal of Eng. \& Tech. 3(3), 487-491.

Mahali1, KP; Sinha, AK (2015). Utilization of stonedust with plastic waste for improving the subgrade in highway pavement construction" International Journal of Research in Engineering and Technology 4 (6) 29-35

Muntohar,S.; Hantoro, G., (2000), "Influence of Rice Husk Ash and Lime on Engineering Properties of a Clayey Sub-grade", Electronic Journal of Geotechnical Engineering, Vol. 5.

Nigerian Federal Ministry of Works, 1997. General specification for roads and bridge works. Federal Government of Nigeria.

Singh YP; Singh RP. 1991. Recycled Plastic Finds Home in Asphalt Binder, Europeans Polymer Journal, 19(6), 539 -542.

Zoorob. SE; Superma, LB (2000). Laboratory design and investigation of proportion of bituminous composite containing waste recycled plastics, aggregate replacement (Plastiphalt), CIB Symposium onConstruction and Environment (Theory into practice) Sao, Brazil.

Wienaah, M. M. Sustainable Plastic Waste Management - A Case of Accra, Ghana, Master Thesis, Department of Polymer Technology, TRITA-LWR , KTH Royal Institute of Technology, Stockholm, Sweden, 2007. 